\title{
ВОЗДЕЛЫВАНИЕ КИНОА В УСЛОВИЯХ ЮЖНОГО ПРИАРАЛЬЯ
}

\author{
Профессор, д-р с.х. наук. Султанова 3. С., \\ Нукусский филиал Ташкентского государственного аграрного университета \\ профессор, кандидат биологических наук, Тодерич К. $\boldsymbol{H}$., \\ Университет Тоттори, Япония
}

DOI: https://doi.org/10.31435/rsglobal_sr/31102019/6749

\section{ARTICLE INFO}

Received 10 August 2019

Accepted 06 October 2019

Published 31 October 2019

\section{KEYWORDS}

quinoa cultivation on marginal conditions, mineral fertilizer rate for quinoa.

\begin{abstract}
The features of the growth and development of quinoa in the conditions of the South Aral Sea region are studied. Marginal conditions have a negative impact on the growth and development of traditional cultures. Therefore, the cultivation of quinoa will provide the population with quality food. An increase in doses of mineral fertilizers has a positive effect on the growth and development of plants, and increases grain yield.
\end{abstract}

Citation: Султанова 3. С., Тодерич К. Н. (2019) Vozdelyvanie Kinoa v Usloviyah Yuzhnogo Priaral'ya. Science Review. 8(25). doi: 10.31435/rsglobal_sr/31102019/6749

Copyright: () 2019 Султанова 3. С., Тодерич К. Н. This is an open-access article distributed under the terms of the Creative Commons Attribution License (CC BY). The use, distribution or reproduction in other forums is permitted, provided the original author(s) or licensor are credited and that the original publication in this journal is cited, in accordance with accepted academic practice. No use, distribution or reproduction is permitted which does not comply with these terms.

Введение. Центрально-Азиатский регион сталкивается с серьезными проблемами в области продовольственной безопасности и необходимостью обеспечения полноценным питанием населения в условиях недостатка поливной воды и прогрессирующей деградацией земель. В связи с этим, последние годы киноа (Chenopodium quinoa Willd.), как многоцелевая агропромышленная культура из региона Анд получила всеобщее признание благодаря своей способности произрастать в самых неблагоприятных почвенно-климатических условиях.

По мнению. ElYoussfi, L., Choukr-Allah, R., Zaafrani, и др. [1; p.306-309], Rao, N. K. [4], положительные достоинства киноа: высокое содержание белка и питательные качества. В зерне киноа содержится в среднем 16,2 процента белка, а в зерне пшеницы в среднем 12-14\%; белок киноа не содержит глютена и легко переваривается. В киноа много клетчатки и фосфора, а также минералов, особенно кальция, цинка, фосфора, железа, меди, магния, марганца, $5 \%$ жира, витаминов В1, В2, С, В, А, Е, К, РР, Д.

Зерно дисковой формы, цвета возделываемых сортов киноа: белый и желтый, диаметр зерна от 1,3 до 2,7 мм, масса 1000 зерен 1.2-6 г, вегетационный период: 120 дней до 150 дней Урожайность зерна: до 250 г/растение.

Результаты исследований. Киноа является одной из самых питательных продовольственных культур известных в настоящее время. Зерно киноа могут использоваться как в питании населения, так и в качестве корма для скота и домашней птицы. В связи с этим цель исследований состояла в выявлении оптимальной нормы минеральных удобрений, обеспечивающих высокий урожай зерна.

Задачи исследований включали: изучение соответствия местных почвенноклиматических условий биологии киноа; изучение влияния норм минеральных удобрений на рост и развитие киноа.

Полевые опыты были проведены в 2017-2018 годах на полях Каракалпакской станции НИИ зерновых и зернобобовых культур. Объектом исследований был сорт киноа Ames 13761, 
который был высеян на пяти фонах минерального фона: 1 . Контроль, без удобрений, $\mathrm{N}_{60} \mathrm{P}_{25} \mathrm{~K}_{20}$, $\mathrm{N}_{120} \mathrm{P}_{50} \mathrm{~K}_{40}, \mathrm{~N}_{180} \mathrm{P}_{80} \mathrm{~K}_{60}, \mathrm{~N}_{240} \mathrm{P}_{100} \mathrm{~K}_{60}$.

При сравнении вариантов опыта, с увеличением нормы внесения удобрений высота растений увеличивается. Так на варианте без удобрений высота растений в фазе полной спелости составила 69 см, при внесении $\mathrm{N}_{240} \mathrm{P}_{100} \mathrm{~K}_{60}-88 \mathrm{~cm}$.

Промывку почвы и влагозарядковый полив проводили с нормой $2500-3000 \mathrm{~m}^{3} /$ га. При созревании почвы вносили фосфорно-калийные удобрения РМУ-0,5 с трактором ТТЗ-80-11. Норму удобрений рассчитывали на действующее вещество с перерасчётом на вносимую площадь делянки. Посев проводили вручную с междурядьями 60 см, между растениями в рядке $15 \mathrm{~cm}$, при дальнейшей прополке всходов оставляли растения в рядке через 22-25 см. По мере появления всходов проводилась нарезка борозд вручную для поддержания почвы в рыхлом состоянии и полива посевов киноа.

Подкормка посевов удобрениями проводилась равномерным разбрасыванием по полю. Норму удобрений устанавливали согласно принятой в опыте нормой внесения. Семена всех киноа высевали на глубину 1,5-2,0 см.

Способы посева -рядовой, с шириной междурядий 60 см. Посев был проведён 27-28 апреля, а второй 7 мая 2018 года. В полевых опытах проводили наблюдения за ростом и развитием сорных растений, вредителей и болезней. При превышении порога вредоносности проводились меры борьбы с ними. Рано весной, когда рост и развитие растений слабый, против сорных растений с учётом развития посевов и состава вредителей в июне и июле месяце проводили обработку посевов химическими препаратами. Уборку проводили в фазе полной спелости зёрен, при появлении внешних признаков созревания растения, пожелтение листьев, достижении твёрдости зерна. Уборка киноа проводилась в несколько сроков по мере созревания растений. Обмолот и очистку зерна киноа после уборки проводили вручную.

По полученным данным, всходы киноа появились на 7-8 день после посева, начало ветвления 20-21 мая, цветение посевов отмечено 17-18 июня, начало образования плодов 27-29 июля и полное созревание плодов сорта Ames $13761(\mathrm{Q} 3)$ - 20 сентября.

Минеральные удобрения положительно влияли на рост и развитие сорта. На высоком агрофоне минерального питания и хорошей влагообеспеченности растений происходит быстрый рост растений и увеличение вегетативной массы. При сравнении вариантов опыта, с увеличением нормы внесения удобрений высота растений увеличивается. Так, высота растений составляла по нормам удобрений $69-88$ см.

Динамика роста растений в высоту. Высота растений является показателем важных хозяйственно-биологических признаков и свойств, проявляется в формировании общей биомассы растений (таблица 1). На высоту растений наряду с сортовыми признаками влияют условия выращивания. Высокие летние температуры, низкая относительная влажность воздуха и частые ветры влияли на высоту растений и другие показатели продуктивности, которое проявлялось в низких показателях роста, меньшем накоплении сухого вещества и меньшей продуктивности посевов по сравнению с другими регионами возделывания [2;3].

Таблица 1. Динамика высоты растений киноа сорта Ames 13761 (Q3) при различной норме внесения минеральных удобрений

\begin{tabular}{|c|c|c|c|c|c|}
\hline \multirow[b]{2}{*}{$\begin{array}{l}\text { Нормы } \\
\text { удобрений }\end{array}$} & \multicolumn{5}{|c|}{ Даты проведения измерений } \\
\hline & $\begin{array}{l}\text { всходы } \\
15.05\end{array}$ & $\begin{array}{l}\text { ветвление } \\
25.05\end{array}$ & $\begin{array}{l}\text { цветение } \\
20.06\end{array}$ & $\begin{array}{l}\text { образование } \\
\text { плодов } 10.07\end{array}$ & $\begin{array}{l}\text { созревание } \\
30.08\end{array}$ \\
\hline $\begin{array}{l}\text { Контроль, } \\
\text { без удобрений }\end{array}$ & 8 & 20 & 60 & 68 & 69 \\
\hline $\mathrm{N}_{60} \mathrm{P}_{25} \mathrm{~K}_{20}$ & 11 & 22 & 72 & 78 & 80 \\
\hline $\mathrm{N}_{120} \mathrm{P}_{50} \mathrm{~K}_{40}$ & 13 & 24 & 77 & 82 & 84 \\
\hline $\mathrm{N}_{180} \mathrm{P}_{80} \mathrm{~K}_{60}$ & 12 & 28 & 79 & 85 & 86 \\
\hline $\mathrm{N}_{240} \mathrm{P}_{100} \mathrm{~K}_{60}$ & 112 & 31 & 82 & 87 & 88 \\
\hline
\end{tabular}

Из-за низкой обеспеченности почвы питательными элементами, минеральные удобрения оказывали положительно влияли на рост и развитие сорта. На высоком агрофоне минерального питания и хорошей влагообеспеченности растений происходил быстрый рост растений и увеличение вегетативной массы. В опытах, с повышением нормы внесения 
минеральных удобрений урожайность повышалась. Повышение урожайности наблюдалось за счёт увеличения среднего числа побегов. Наиболее высокие показатели урожайности наблюдались при внесении $\mathrm{N}_{240} \mathrm{P}_{100} \mathrm{~K}_{60}$ (таблица 2).

Так, урожайность зерна на контроле без удобрений составила 3,7 ц/га; на варианте $\mathrm{N}_{60} \mathrm{P}_{25} \mathrm{~K}_{20}-6,7$ ц/га; на варианте $\mathrm{N}_{120} \mathrm{P}_{50} \mathrm{~K}_{40}-7,8$ ц/га; на варианте $\mathrm{N}_{180} \mathrm{P}_{80} \mathrm{~K}_{60}-9,1$ ц/га и на варианте $\mathrm{N}_{240} \mathrm{P}_{100} \mathrm{~K}_{60}-11,6$ ц/га. Наряду с формированием большего числа побегов, растения имели большую длину кисти: от 22,5 см на контроле, без удобрений, до - 27,3 см при внесении $\mathrm{N}_{240} \mathrm{P}_{100} \mathrm{~K}_{60}$. При внесении $\mathrm{N}_{60} \mathrm{P}_{25} \mathrm{~K}_{20}$, длина кисти составила $-23,5$ см, при внесении $\mathrm{N}_{120} \mathrm{P}_{50} \mathrm{~K}_{40}-$ 25,1 см, при внесении $\mathrm{N}_{180} \mathrm{P}_{80} \mathrm{~K}_{60}-26,4$ см и при внесении $\mathrm{N}_{240} \mathrm{P}_{100} \mathrm{~K}_{60}$ отмечены самые высокие показатели $-27,3$ см. Масса побегов без зерна - один из основных показателей продуктивности посевов, так как солома может использоваться на корм скоту и на другие цели. Этот показатель

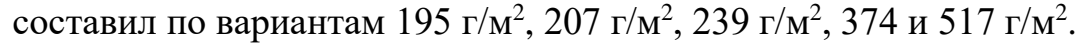

Таблица 2. Урожайность зерна и структура урожая киноа сорта Ames13761 (Q3) при различной норме внесения минеральных удобрений

\begin{tabular}{|l|l|l|l|l|}
\hline Норма удобрений & $\begin{array}{l}\text { Количество } \\
\text { побегов, шт. }\end{array}$ & $\begin{array}{l}\text { Длина кисти, } \\
\text { см }\end{array}$ & $\begin{array}{l}\text { Масса } \\
\text { побегов, г }\end{array}$ & $\begin{array}{l}\text { Урожайность } \\
\text { зерна, ц/га }\end{array}$ \\
\hline Контроль, без удобрений & 8,2 & 22,5 & 195 & 3,4 \\
\hline $\mathrm{N}_{60} \mathrm{P}_{25} \mathrm{~K}_{20}$ & 8,6 & 23,5 & 207 & 6,7 \\
\hline $\mathrm{N}_{120} \mathrm{P}_{50} \mathrm{~K}_{40}$ & 9,6 & 25,1 & 239 & 7,8 \\
\hline $\mathrm{N}_{180} \mathrm{P}_{80} \mathrm{~K}_{60}$ & 10,2 & 26,4 & 374 & 9,1 \\
\hline $\mathrm{N}_{240} \mathrm{P}_{100} \mathrm{~K}_{60}$ & 11,3 & 27,3 & 517 & 11,6 \\
\hline
\end{tabular}

Урожайность складывается из региональных приёмов возделывания, которые в нашем случае включали: первое - технологию рыхления почвы вокруг растений, как это принято для других широкорядных растений, с целью обеспечения доступа воздуха и снятия солей вокруг растений; второе - подкормку растений в начальные фазы развития, когда рост и развитие идет очень медленно (азотными и фосфорными растениями); третье - борьба с вредителями, имеющими место в естественной резервации с помощью химических препаратов.

По проведённым исследованиям по изучению киноа в первый год исследований можно сделать следующие выводы:

1. Растения киноа хорошо произрастают на засолённых почвенно-климатических условиях Южного Приаралья и формируют урожаи, близкие к таким условиям.

2. Внесение минеральных удобрений способствует формированию хороших показателей продуктивности сорта Ames 13761 (Q3), поэтому можно сказать, что минеральные удобрения являются эффективным средством для накопления более высокого урожая.

\section{ЛИТЕРАТУРА}

1. El Youssfi, L., Choukr-Allah, R., Zaafrani, M., Mediouni, T., Ba Samba, M., and Hirich, A. (2012). Effect of domestic treated wastewater use on three varieties of Quinoa (Chenopodium quinoa) under semi arid conditions. World Acad. Sci. Eng. Technol. 68, 306-309.

2. Ashraf, M. (2014). Stress-induced changes in wheat grain composition and quality. Crc. Rev. Food. Sci. Nutr. 54, 1576-1583. doi: 10.1080/10408398.2011.644354

3. Hirich, A. (2014). Effects of Deficit Irrigation using Treated Wastewater and Irrigation with Saline Water on Legumes, Corn and Quinoa Crops. Ph.D., thesis, Hassan II Institue of Agronomy and Veterinary Medicine, Morocco.

4. Rao, N. K. (2016). "Quinoa: a future-proof crop for climate smart agriculture," in Global Forum for Innovations in Agriculture-2016, ed R. Choukr-Allah (Abu Dhabi). 